\title{
Cessation of Renin-Angiotensin System Antagonists During the SARS-CoV-2 Pandemic - Do We Have the Evidence?
}

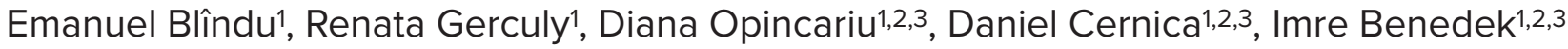 \\ ${ }^{1}$ Clinic of Cardiology, Emergency Clinical County Hospital, Târgu Mureș, Romania \\ 2 "George Emil Palade" University of Medicine, Pharmacy, Science and Technology, Târgu Mureș, Romania \\ ${ }^{3}$ Center of Advanced Research in Multimodality Cardiac Imaging, CardioMed Medical Center, Târgu Mureș, Romania
}

\section{CORRESPONDENCE}

Renata Gerculy

Str. Gheorghe Marinescu nr. 50

540136 Târgu Mureș, Romania

Tel: +40265212 111

E-mail gerculy_renata@yahoo.com

\section{ARTICLE HISTORY}

Received: July 17, 2020

Accepted: August 15, 2020
Emanuel Blîndu • Str. Gheorghe Marinescu nr. 50, 540136 Târgu Mures, Romania. Tel: +40 265212 111, E-mail: emi.blindu@yahoo.com

Diana Opincariu • Str. Gheorghe Marinescu nr. 38 , 540139 Târgu Mureș, Romania. Tel: +40 265215 551, E-mail: diana.opincariu@yahoo.com

Daniel Cernica • Str. Gheorghe Marinescu nr. 38, 540139 Târgu Mureș, Romania. Tel: +40 265215551 , E-mail: daniel.cernica@gmail.com

Imre Benedek • Str. Gheorghe Marinescu nr. 38 540139 Târgu Mureș, Romania. Tel: +40 265215551 E-mail: imrebenedek@yahoo.com

\begin{abstract}
The aim of this review is to provide a short update on whether treatment with angiotensinconverting enzyme inhibitors (ACEls) or angiotensin receptor blockers (ARBs) has beneficial or harmful effects in patients infected with SARS-CoV-2. Epidemiological studies have shown that SARS-CoV-2 infects all age groups, presenting a higher incidence in elderly patients with various comorbidities such as hypertension, diabetes mellitus, and cardiovascular diseases. A large proportion of these patients are treated with ACEls and ARBs. Since it has been demonstrated that SARS-CoV-2 uses angiotensin converting enzyme type 2 (ACE2) as an entry point into host cells, it is important to know whether ACEls and ARBs could modify the expression of this enzyme, and thus promote the viral infection. Animal studies and a few studies in humans have shown that renin angiotensin system (RAS) inhibitors increase tissue expression of ACE2, but with potentially beneficial effects. In this context, it is imperative to provide appropriate guidance for clinicians and patients. The major cardiology associations across the world have released statements in which they recommend healthcare providers and patients to continue their treatments for hypertension and heart failure as prescribed.
\end{abstract}

Keywords: COVID-19, ACE2, angiotensin-1-7, RAS inhibitors

\section{INTRODUCTION}

In December 2019, a number of cases of atypical pneumonia with an unknown pathogen were reported in Wuhan City, Hubei Province, China. The pathogen was later identified as a member of the Coronaviridae family and was named severe acute respiratory syndrome coronavirus 2 (SARS-CoV-2), while the disease caused is called coronavirus disease 2019 (COVID-19). The severe acute respiratory syndrome coronavirus (SARS-CoV) and Middle East respiratory syndrome-related coronavirus (MERS-CoV) are also part of this family. As a side note, this is the third consecutive decade in which a coronavirus crosses species to infect humans (SARS-CoV has infected more than 8,000 people in 
2002-2003, and MERS-CoV has infected more than 2,500 people since 2012).1,2 On January 13, the first case of COVID-19 infection was reported outside of China, while in Europe, the first case was reported on January 24. Due to the high rate of contagion and the aggressiveness of the disease, but also due to the lack of reactivity from the authorities, on March 11, the World Health Organization declared it a pandemic. Until the middle of June 2020, there were 7,670,880 confirmed cases and 427,097 deaths, across 311 countries worldwide. ${ }^{3}$ Unfortunately, in the absence of an effective treatment or medical intervention, attempts to control the spread of the infection have relied on nonpharmaceutical intervention. This includes promotion of personal hygiene, social distancing, closing of schools and other public places, identification of infected cases and their contacts, and also preparation of health systems for a wave of severely ill patients who require intensive care and isolation. ${ }^{4}$

From the beginning of the pandemic it was shown that positive patients were more likely to have hypertension, diabetes mellitus, and other cardiovascular diseases, and had a clear indication for treatment with angiotensin-converting enzyme inhibitors (ACEIs) or angiotensin receptor blockers (ARBs). This had given rise to several concerns because SARS-CoV-2 uses angiotensin-converting enzyme type 2 (ACE2) to enter the host cells. Also, renin angiotensin system (RAS) inhibitors increase the expression of ACE2, presumably resulting in higher infectivity of SARS$\mathrm{CoV}-2$, with development of a more severe form of the disease. ${ }^{5,6}$ Because of these hypotheses, the rapidly evolving nature of the infection, and also panic spread via news and social media, official statements based on medical evidence were necessary for both clinicians and patients.

The aim of this paper is to offer a brief look at the current evidence regarding the continuation or interruption of treatment with ACEIs and ARBs in the context of the COVID-19 pandemic.

\section{CLINICAL PROFILE OF PATIENTS THAT ARE VULNERABLE TO COVID-19 INFECTION AND COMPLICATIONS}

Initial epidemiological studies have shown that SARSCoV-2 infects all age groups, but elderly male patients with comorbidities, especially cardiovascular diseases, hypertension, or diabetes have a higher risk of developing a more severe form, requiring admission to the intensive care unit and mechanical ventilation. ${ }^{7,8}$ An observational study on 8,910 patients with COVID-19 found that old age, coronary heart disease, heart failure, a history of cardiac arrhythmias, chronic obstructive pulmonary disease, and smoking were associated with a higher risk of in-hospital death. ${ }^{9}$ In this context, many clinicians and patients had become aware of the possible interrelation between SARS$\mathrm{CoV}-2$ and the RAS. Due to the high global prevalence of hypertension, estimated at 1.13 billion in 2015, a high number of patients are likely be treated with RAS antagonists (ACEIs or ARBs). ${ }^{10}$ The majority of studies regarding COVID-19 patients did not take into account the treatment for various comorbidities, and therefore the number of patients taking ACEIs or ARBs is unclear. However, two studies have shown that $15-20 \%$ of hospitalized patients were on treatment with ACEIs or ARBs, and about $50 \%$ of them discontinued treatment during hospitalization. ${ }^{9,11}$

\section{WHAT IS THE LINK BETWEEN THE RAS AND SARS-CoV-2?}

The RAS plays a central role in blood pressure regulation. Renin is an enzyme that is synthesized and released by the juxtaglomerular cells in response to decreased blood pressure and low sodium levels, or due to an increased activation of the sympathetic nervous system. Renin converts the enzymatically inactive angiotensinogen to angiotensin $\mathrm{I}$, which is transformed into angiotensin II by the angiotensin-converting enzyme (ACE), present in the endothelium of lung vessels. Angiotensin II is a strong vasoconstrictor, particularly at the level of arterioles, acting on both the short- and long-term regulation of blood pressure and increasing peripheral vascular resistance. Angiotensin II also reduces sodium excretion by stimulating the release of aldosterone. Besides hemodynamic effects, angiotensin II stimulates the inflammatory response and promotes the generation of reactive oxygen species. ${ }^{12}$ Angiotensin II is then converted to angiotensin-1-7 (Ang-1-7) by the membrane-bound ACE 2. Ang-1-7 causes vasodilation and presents anti-inflammatory and antifibrotic effects. Thus, ACE2 has two effects: reducing plasma concentrations of angiotensin II (decreasing vasoconstriction) and production of Ang-1-7 (increasing vasodilation). ${ }^{13}$ Despite its beneficial effects, ACE2 has a dark side: SARS-CoV-2 uses this enzyme for gaining access into host cells. Binding and entry of SARS-CoV-2 is facilitated by attachment between the $\mathrm{S}$ (spike) protein located on the viral envelope and the enzymatic domain of ACE2. ${ }^{14}$ However, a cofactor represented by the serine protease TMPRSS 2 is needed for priming the $S$ protein and activating the entry process. ${ }^{15,16}$ Expression of both ACE2 and TMPRSS2 has been found in human nasal and respiratory tissues, bronchial epithelium, and type II alveolar cells. ${ }^{17}$ 
Thus, ACE2 may be considered the link between the RAS and SARS-CoV-2. However, the question still remains whether ACEIs and ARBs can influence the concentration of ACE2 and modify the course of SARS-CoV2 infection. ACEIs and ARBs are first-choice medication used for the treatment of hypertension and heart failure. In the past few months, the usefulness of RAS inhibitors has become an issue due to lack of proper clinical data on their effects in the setting of COVID-19. The main concern is that ACEIs or ARBs could increase the level of ACE2, leading to a higher number of viral entry points and increasing the susceptibility to infection or severity of the disease. The dilemma arose from the fact that increased levels of ACE2 reduce inflammation and can lead to a milder form of lung injury. Currently, there are two hypotheses regarding this mecha- nism. One states that RAS inhibition may have a harmful effect by increasing ACE2 levels and thereby promoting viral entry. The second hypothesis claims that RAS inhibition decreases angiotensin II synthesis and using ARB prevents angiotensin II from binding to angiotensin II type I receptor (AT1R) and also stabilizes the AT1R-ACE2 complex. This is subsequently preventing ACE2 internalization and degradation, with a weaker inflammatory response and attenuated lung injury. ${ }^{18}$ These classes of medications do not interact directly with ACE2 because they do not bind and inhibit the active site of the enzyme, but there has been significant evidence in animal studies that showed increased expression of ACE2 after treatment with ARBs and ACEIs. ${ }^{19,20}$ Angiotensin II treatment promoted ACE2 internalization, leading to a significant reduction in

TABLE 1. Outcomes of the main studies investigating the relationship between Sars-CoV-2 infection and the use of ACE inhibitors or angiotensin receptor blockers

\begin{tabular}{|c|c|c|c|c|}
\hline Study & Population & Aim & Finding & Commentary \\
\hline Mehra et al. ${ }^{9}$ & $\begin{array}{l}\text { 8,910 patients who were } \\
\text { discharged alive or died }\end{array}$ & $\begin{array}{l}\text { Relationship of cardiovas- } \\
\text { cular disease and drug } \\
\text { therapy with in-hospital } \\
\text { death among hospitalized } \\
\text { patients with COVID-19 }\end{array}$ & $\begin{array}{l}\text { No increased risk of in- } \\
\text { hospital death was found to } \\
\text { be associated with the use } \\
\text { of ACEls or ARBs }\end{array}$ & $\begin{array}{l}\text { Factors associated with increased } \\
\text { risk of in-hospital death: }>65 \text { years, } \\
\text { coronary artery disease, heart } \\
\text { failure, cardiac arrhythmia, chronic } \\
\text { obstructive pulmonary disease, } \\
\text { current smoking }\end{array}$ \\
\hline Meng et $a l^{32}$ & $\begin{array}{l}51 \text { positive patients with } \\
\text { hypertension }\end{array}$ & $\begin{array}{l}\text { Ability of RAS inhibitors to } \\
\text { protect against COVID-19 in } \\
\text { patients with hypertension }\end{array}$ & $\begin{array}{l}\text { Therapy with ACEls or } \\
\text { ARBs was associated with } \\
\text { decreased viral load }\end{array}$ & \\
\hline Mancia et al..$^{33}$ & $\begin{array}{l}6,272 \text { positive patients } \\
30,759 \text { controls }\end{array}$ & $\begin{array}{l}\text { Association between the } \\
\text { use of RAS inhibitors and } \\
\text { susceptibility to COVID-19 }\end{array}$ & $\begin{array}{l}\text { ACEIs and ARBs were not } \\
\text { associated with the risk for } \\
\text { COVID-19 infection }\end{array}$ & $\begin{array}{l}\text { Use of ACEls or ARBs did not show } \\
\text { any association with mortality in } \\
\text { positive patients }\end{array}$ \\
\hline Reynolds et al. ${ }^{34}$ & $\begin{array}{l}12,594 \text { patients tested for } \\
\text { COVID-19 and taking antihy- } \\
\text { pertensive drugs }\end{array}$ & $\begin{array}{l}\text { Relation between five } \\
\text { classes of antihypertensive } \\
\text { drugs (ACEI, ARB, BB, CCB, } \\
\text { thiazide diuretics) and likeli- } \\
\text { hood of a positive test }\end{array}$ & $\begin{array}{l}\text { No class of antihyperten- } \\
\text { sion drugs was associated } \\
\text { with an increase in the risk } \\
\text { for testing positive }\end{array}$ & \\
\hline Mehta et $a / .35$ & 18,472 tested for COVID-19 & $\begin{array}{l}\text { Association between use of } \\
\text { ACEls or ARBs with testing } \\
\text { positive for COVID-19 }\end{array}$ & $\begin{array}{l}\text { No association between } \\
\text { ACEI or ARB use and CO- } \\
\text { VID-19 test positivity }\end{array}$ & \\
\hline de Abajo et al. ${ }^{36}$ & $\begin{array}{l}\text { 1,139 positive patients11,390 } \\
\text { controls }\end{array}$ & $\begin{array}{l}\text { Use of RAS inhibitors and } \\
\text { risk for admission to hospi- } \\
\text { tal in COVID-19 patients }\end{array}$ & $\begin{array}{l}\text { RAS inhibitors did not } \\
\text { increase risk of COVID-19 } \\
\text { requiring admission }\end{array}$ & $\begin{array}{l}\text { Patients with diabetes mellitus and } \\
\text { treatment with RAS inhibitors had a } \\
\text { lower risk for hospital admission }\end{array}$ \\
\hline \multirow[t]{2}{*}{ Khera et $a l^{37}$} & $\begin{array}{l}\text { a) } 853 \text { positive outpatients } \\
\text { receiving ACEIs or ARBs } \\
\text { vs. } 853 \text { positive outpatients } \\
\text { receiving other antihyper- } \\
\text { tensive drugs }\end{array}$ & $\begin{array}{l}\text { Use of ACEIs or ARBs and } \\
\text { risk for hospitalization }\end{array}$ & $\begin{array}{l}\text { Patients receiving ACEIs } \\
\text { were less frequently } \\
\text { hospitalized than those } \\
\text { receiving other antihyper- } \\
\text { tensive drugs. There was } \\
\text { no significant association } \\
\text { between ARB therapy and } \\
\text { hospitalization. }\end{array}$ & \\
\hline & $\begin{array}{l}\text { b) } 1,731 \text { COVID-19 patients } \\
\text { taking ACEls and } 1,580 \\
\text { COVID-19 patients taking } \\
\text { ARBs matched to COVID-19 } \\
\text { patients taking other antihy- } \\
\text { pertensive drugs }\end{array}$ & $\begin{array}{l}\text { Mortality in inpatient cohort } \\
\text { receiving ACEIs or ARBs } \\
\text { vs. inpatient cohort taking } \\
\text { other antihypertensive } \\
\text { drugs }\end{array}$ & $\begin{array}{l}\text { Mortality did not differ be- } \\
\text { tween inpatient groups }\end{array}$ & \\
\hline
\end{tabular}


its enzymatic activity on the cell membrane. Losartan not only prevented internalization and degradation of ACE2, but also increased its expression 3 -fold. ${ }^{21}$ In two lung injury animal models, the activation of angiotensin type 1 receptors had led to increased intensity of tissue injury, while a marked signaling of the ACE2 system has reduced the harmful effects. ${ }^{19,22}$ Another study showed that in mice, gene expression of ACE2 was increased 5-fold and 3-fold after treatment with lisinopril and losartan, respectively. ${ }^{13}$ Of note, in mice, the loss of ACE is associated with resistance to SARS-CoV-2 infection, but also with increased vascular permeability, edema, leucocyte infiltration, and lung injury. ${ }^{19,20}$ Conversely, overexpression of the ACE2 gene favored a better outcome after myocardial infarction in remodeling and improving ejection fraction. . $3,24^{24}$

In humans, the effects of RAS inhibitors on the activity of ACE2 and Ang-1-7 are scarce. The blockade of AT1R, achieved by the administration of losartan or olmesartan, was accompanied by significant upregulation of ACE2 expression and increased levels of Ang-1-7.25 Similarly, in another study, Ang-1-7 levels were not modified after initial treatment with captopril in patients with hypertension, but after exposure to captopril for 6 months, the level of ANG1-7 increased. ${ }^{26}$ The majority of data regarding the effect of RAS inhibitors on ACE2 expression was acquired from preclinical models and may not always translate to human physiology. Although ACE2 is insensitive to ACEIs, studies have shown that ACEI treatment in patients with viral pneumonia was associated with improved outcomes..$^{27-30}$ Furthermore, treatment with RAS inhibitors was associated with a reduction in viral load. This was probably an indirect effect of these drugs, resulting from the regulation of the immune response and inhibition of the inflammatory pathways rather than due to a direct blockage of virus replication. ${ }^{31,32}$

In several studies, treatment with ACEIs or ARBs was not associated either with a higher incidence of COVID-19 infection, or with more severe forms of infection or worse outcomes. One study even showed that the group of patients taking ACEIs/ARBs had a lower risk of mortality compared to controls, who have been prescribed a different anti-hypertensive regimen. , $32-37^{-3}$

Table 1 shows the main results of the studies investigating the link between ACE inhibition and SARS-CoV-2 infection.

The effects of treatment with ACEIs/ARBs in patients infected with SARS-CoV-2 are not fully understood. However, the cessation of RAS inhibitors, in the absence of a clear evidence or established reason, may have deleterious effects on the underlying cardiovascular disease. ${ }^{38,39} \mathrm{Al}-$ though these drugs produce an increase in ACE2 expression, thus promoting viral entry in host cells, it seems that patients on this medication have a lower risk for developing a more severe illness or worse outcomes. The Council of Hypertension of the ESC released a statement that strongly advises physicians and patients to continue treatment with their prescribed anti-hypertensive medication; there is no scientific evidence to demonstrate that treatment with ACEIs and ARBs should be discontinued in the presence of SARS-CoV-2 infection. ${ }^{40}$ Also the American Heart Association, the Heart Failure Society of America, and the American College of Cardiology are advocating that patients should continue treatment with RAS inhibitors prescribed for hypertension, ischemic heart disease, and heart failure. Changes in medications should be made only after careful assessment and based on the latest scientific evidence. ${ }^{41}$

\section{CONCLUSIONS}

Even though the major cardiology associations have released statements regarding the safety of continuing treatment with ACEIs and ARBs, the role of these drugs in SARS-CoV-2 infection is still under debate. There is a lack of solid scientific evidence regarding the discontinuation of treatments with RAS inhibitors in patients with COVID-19 and cardiovascular diseases. Although additional data may further shed light on the benefits and disadvantages of treatment with ACEIs and ARBs, physicians need to consider the undesirable results of discontinuing proven therapies in response to concerns that currently are not based on solid data.

\section{CONFLICT OF INTEREST}

Nothing to declare.

\section{REFERENCES}

1. SARS (Severe Acute Respiratory Syndrome). Available at: https://www. who.int/ith/diseases/sars/en/

2. Middle East respiratory syndrome coronavirus (MERS-CoV) - The Kingdom of Saudi Arabia. Available at: https://www.who.int/csr/don/24february-2020-mers-saudi-arabia/en/

3. WHO Coronavirus Disease (COVID-19) Dashboard. Available at: https:// covid19.who.int/

4. Bedford J, Enria D, Giesecke J, et al. COVID-19: towards controlling of a pandemic. Lancet. 2020;395:1015-1018.

5. Fang L, Karakiulakis G, Roth M. Are patients with hypertension and diabetes mellitus at increased risk for COVID-19 infection? Lancet Respir Med. 2020;8:e21.

6. Esler M, Esler D. Can angiotensin receptor-blocking drugs perhaps be harmful in the COVID-19 pandemic? J Hypertens. 2020;38:781-782.

7. Guan WJ, Ni ZY, Hu Y, et al. Clinical characteristics of coronavirus disease 2019 in China. N Engl J Med. 2020;382:1708-1720. 
8. Onder G, Rezza G, Brusaferro S. Case-Fatality Rate and Characteristics of Patients Dying in Relation to COVID-19 in Italy. JAMA. 2020;323:1775-1776.

9. Mehra MR, Desai SS, Kuy S, Henry TD, Patel AN. Cardiovascular disease, drug therapy, and mortality in Covid-19. N Engl J Med. 2020;382:e102.

10. NCD Risk Factor Collaboration. Worldwide trends in blood pressure from 1975 to 2015: a pooled analysis of 1479 population-based measurement studies with 19.1 million participants. Lancet. 2017;389:37-55.

11. Richardson S, Hirsch JS, Narasimhan M, el al. Presenting Characteristics, Comorbidities, and Outcomes Among 5700 Patients Hospitalized With COVID-19 in the New York City Area. JAMA. 2020;323:2052-2059.

12. Sparks MA, Crowley SD, Gurley SB, Mirotsou M, Coffman TM. Classical renin- angiotensin system in kidney physiology. Compr Physiol. 2014;4:1201-1228

13. Ferrario CM, Trask AJ, Jessup JA. Advances in biochemical and functional roles of angiotensin-converting enzyme 2 and angiotensin-(1-7) in regulation of cardiovascular function. Am J Physiol Heart Circ Physiol. 2005;289:H2281-2290.

14. Wang K, Gheblawi M, Oudit GY. Angiotensin Converting Enzyme 2: A Double-Edged Sword. Circulation. 2020. [Epub ahead of print]

15. Hoffmann M, Kleine-Weber H, Schroeder S, et al. SARS-CoV-2 Cell Entry Depends on ACE2 and TMPRSS2 and Is Blocked by a Clinically Proven Protease Inhibitor. Cell. 2020;181:271-280.

16. Matsuyama S, Nagata N, Shirato K, Kuwase M, Takeda M, Taguchi F. Efficient activation of the severe acute respiratory syndrome coronavirus spike protein by the transmembrane protease TMPRSS2. J Virol. 2010;84:12658-12660.

17. Bertram S, Heurich A, Lavender $\mathrm{H}$, et al. Influenza and SARS-coronavirus activating proteases TMPRSS2 and HAT are expressed at multiple sites in human respiratory and gastrointestinal tracts. PLoSOne. 2012;7:e35876.

18. South, AM, Tomlinson L, Edmonston D, Hiremath S, Sparks MA. Controversies of renin-angiotensin system inhibition during the COVID-19 pandemic. Nat Rev Nephrol. 2020;16:305-307.

19. Kuba K, Imai Y, Rao S, et al. A crucial role of angiotensin converting enzyme 2 (ACE2) in SARS coronavirus-induced lung injury. Nat Med. 2005;11:875-876

20. Ocaranza MP, Godoy I, Jalil JE. Enalapril Attenuates Downregulation of Angiotensin-Converting Enzyme 2 in the Late Phase of Ventricular Dysfunction in Myocardial Infarcted Rat. Hypertension. 2006;48:572-578.

21. Deshotels MR, Xia H, Sriramula S, Lazartigues E, Filipeanu CM. Angiotensin II Mediates Angiotensin Converting Enzyme Type 2 Internalization and Degradation Through an Angiotensin || Type I Receptor-Dependent Mechanism. Hypertension. 2014;64:1368-1375.

22. Imai Y, Kuba K, Rao S, et al. Angiotensin-converting enzyme 2 protects from severe acute lung failure. Nature. 2005;436:112-116.

23. Crackower M, Sarao R, Oudit GY, et al. Angiotensin-converting enzyme 2 is an essential regulator of heart function. Nature. 2002;417:822-828.

24. Huentelman MJ, Grobe JL, Vazquez J. Protection from angiotensin IIinduced cardiac hypertrophy and fibrosis by systemic lentiviral delivery of ACE2 in rats. Exp Physiol. 2005;90:783-790.

25. Ishiyama Y, Gallagher PE, Averill DB, Tallant EA, Brosnihan KB, Ferrario $\mathrm{CM}$. Upregulation of angiotensin-converting enzyme 2 after myocardial infarction by blockade of angiotensin $\|$ receptors. Hypertension. 2004:43:970]976.
26. Luque M, Martin P, Martell N, Fernandez C, Brosnihan KB, Ferrario $\mathrm{CM}$. Effects of captopril related to increased levels of prostacyclin and angiotensin-(1-7) in essential hypertension. J Hypertens. 1996;14:799-805.

27. Arendse LB, Danser AHJ, Poglitsch M, et al. Novel therapeutic approaches targeting the renin-angiotensin system and associated peptides in hypertension and heart failure. Pharmacol Rev. 2019;71:539-570.

28. Tipnis SR, Hooper NM, Hyde R, Karran E, Christie G, Turner AJ. A human homolog of angiotensin-converting enzyme. Cloning and functional expression as a captopril insensitive carboxypeptidase. J Biol Chem. 2000;275:33238-33243.

29. Mortensen EM, Pugh MJ, Copeland LA, et al. Impact of statins and angiotensin-converting enzyme inhibitors on mortality of subjects hospitalised with pneumonia. Eur Resp J. 2008;31:611-617.

30. Christopher H, Manaf Z, Stock E, Ghamande S, Arroliga AC, White HD. Impact of angiotensin-converting enzyme inhibitors and statins on viral pneumonia. Baylor University Medical Center Proceedings. 2018;31:419-423.

31. Yang G, Tan Z, Zhou L, et al. Angiotensin II receptor blockers and angiotensin-converting enzyme inhibitors usage is associated with improved inflammatory status and clinical outcomes in COVID-19 patients with hypertension. medRxiv. 2020. [Epub ahead of print]

32. Meng J, Xiao G, Zhang J, et al. Renin-angiotensin system inhibitors improve the clinical outcomes of COVID-19 patients with hypertension. EmergMicrob Infect. 2020;9:757-760.

33. Mancia G, Rea F, Ludergnani M, Apolone G, Corrao G. Renin-angiotensinaldosterone system blockers and the risk of Covid-19. N Engl J Med. 2020;NEJMoa2006923

34. Reynolds HR, Adhikari S, Pulgarin C, et al. Renin-angiotensinaldosterone system inhibitors and risk of Covid-19. N Engl J Med. 2020;NEJMoa2008975

35. Mehta M, Kalra A, Nowacki AS, et al. Association of Use of AngiotensinConverting Enzyme Inhibitors and Angiotensin II Receptor Blockers With Testing Positive for Coronavirus Disease 2019 (COVID-19). JAMA Cardiol. 2020;e210855

36. de Abajo FJ, Rodriguez-Martin S, Lerma V, et al. Use of renin-angiotensinaldosterone system inhibitors and risk of COVID-19 requiring admission to hospital: a case population study. Lancet. 2020;395:1705-1714.

37. Khera R, Clark C, Lu Y, et al. Association of angiotensin-converting enzyme inhibitors and angiotensin receptor blockers with the risk of hospitalization and death in hypertensive patients with Coronavirus Disease-19. medRxiv. 2020;20104943.

38. Shi S, Qin M, Shen B, et al. Association of Cardiac Injury With Mortality in Hospitalized Patients With COVID-19 in Wuhan, China. JAMA Cardiol. 2020;e200950.

39. Wang D, Hu B, Hu C, et al. Clinical Characteristics of 138 Hospitalized Patients With 2019 Novel Coronavirus-Infected Pneumonia in Wuhan, China. JAMA. 2020;323:1061-1069.

40. European Society of Cardiology. Position statement of the ESC Council on Hypertension on ACE-inhibitors and angiotensin receptor blockers. 13 Mar 2020. Available at: https://www.escardio.org/Councils/Councilon-Hypertension-(CHT)/News/position-statement-of-the-esc-council-onhypertension-on-ace-inhibitors-and-ang

41. American Heart Association. HFSA/ACC/AHA statement addresses concerns re: using RAAS antagonists in COVID-19. Available at: https:// www.acc.org/latest-in-cardiology/articles/2020/03/17/08/59/hfsa-acc-ahastatement-addresses-concerns-re-using-raas-antagonists-in-covid-19. 